\title{
Hybrid Sepic-Ćuk DC-DC Converter Associated to a SRM Drive for a Solar PV Powered Water Pumping System
}

\author{
Armando Cordeiro ${ }^{1,2,3,4}$, Miguel Chaves ${ }^{1,3}$, \\ Hiren Canacsinh ${ }^{1,3,9}$, Ricardo Luís ${ }^{1,2,3}$ \\ ${ }^{1}$ ISEL, ADEEEA, Instituto Politécnico de Lisboa, \\ ${ }^{2}$ LCEC, ${ }^{9}$ GIAAPP, \\ Lisboa, Portugal \\ \{acordeiro, mchaves, hic, rluis\} @ deea.isel.ipl.pt;
}

\author{
Vítor F. Pires ${ }^{3,4,5}$, Daniel Foito ${ }^{4,5,7}$, \\ A. J. Pires ${ }^{4,5,7}$ \\ ${ }^{3}$ INESC-ID, ${ }^{4}$ Sustain.RD, ${ }^{5}$ ESTSetúbal, \\ Instituto Politéc.de Setúbal, \\ Setúbal, Portugal \\ \{vitor.pires, daniel.foito, \\ armando.pires\}@estsetubal.ips.pt
}

\author{
João F. Martins ${ }^{6,7}$ \\ ${ }^{6} \mathrm{DEEC} / \mathrm{FCT} / \mathrm{UNL}$ \\ ${ }^{7} \mathrm{CTS}$ - Uninova \\ Lisboa, Portugal \\ jf.martins@fct.unl.pt
}

\begin{abstract}
The present paper describes a solar photovoltaic (SPV) powered water pumping system employing a switched reluctance motor (SRM) and a merged Sepic-Ćuk DC-DC converter. The proposed solution was designed to use efficiently the available solar energy in order to supply water pumping systems. Solutions of this kind assume a special importance in the current scenario of natural and renewable resources optimization. The proposed DC-DC converter operates in continuous conduction mode (CCM), which combined with a maximum power point tracking (MPPT) controller, helps to optimize the power of the solar photovoltaic panel (SPV). The proposed DC-DC topology is characterized by high voltage static gain when compared with the classical boost topology and reduced voltage stress across the power switch and diodes. Several simulation and experimental results are presented in order to confirm the characteristics of the proposed solution for water pumping systems.
\end{abstract}

Keywords-DC-DC converter; Sepic-Ćuk converter; Water pumping system; Photovoltaic panel; SRM drive.

\section{INTRODUCTION}

There is currently a widespread concern about climate change and development of more efficient and environmentally friendly solutions. In this context, some of the most promising solutions, whether isolated or connected to the distribution network, are those which make use of renewable energy sources based on wind turbines, solar photovoltaic panels (SPV) and hydrogen [1]-[4]. According to the latest report available online from the International Energy Agency (IEA), renewables broke new records in 2016, mainly due to the deployment of solar photovoltaic solutions around the world with special focus on People's Republic of China as a consequence of mass production, policy support, reduction of costs and development of new technologies [5]. China is also the world market leader in hydropower and bioenergy for electricity and heat, as well as electric vehicles. For the first time, solar PV additions rose faster than any other fuel, surpassing the net growth in coal. Throughout 2016, photovoltaic solar capacity installed worldwide grew around

This work was supported by Instituto Politécnico de Lisboa, Projetos IDI\&CA 2019 - SOLARPUMP.
$50 \%$, reaching more than $74 \mathrm{GW}$.

There are many applications where photovoltaic solar panels can be used, from domestic, commercial or industrial applications (for self-consumption essentially) and from decentralized power generation to supply isolated loads or connected to the local distribution network. An important application related with isolated loads is the water pumping systems to human consumption, animals or faunas and irrigation channels in agriculture, especially applied in remote places where no electricity supply is available or the investment costs in such infrastructures are substantial [6, 7]. There are, in many places around the world, pumping systems using internal combustion engines (mainly diesel) with the inherent disadvantages of fossil fuel prices (including transportation costs), environmental pollution (noise and smoke), high maintenance costs, low reliability and low efficiency. To overcome some of these disadvantages, several solutions of pumping systems powered by SPV have emerged in recent years [8]-[10], providing low operating and maintenance costs, robustness, reliability and autonomous operating capacity. Typically, water pumping systems are driven by direct current (DC) or alternating current (AC) motors [11]-[13]. A detailed comparison between permanent magnet DC motors (PMDC) and AC motors for solar-powered water pumping systems is discussed in [14, 15]. Switched Reluctance Motors (SRM) are also a suitable alternative for use in pumping systems due to their robustness, low inertia, low cost, simplicity of operation and potential to work in hostile environments, [10], [16]. In addition, this type of motor can be driven by a simple converter powered by a DC power source.

The research work presented in this paper aims to explore the potential of the SRM driven by solar photovoltaic systems (SPV and energy processing system) for water pumping application, but with potential to many other solutions. DC-DC converters are power electronic circuits that are essential for these applications. Due to the application type they should present characteristics as continuous input current and high voltage gain. Several DC-DC converters with those characteristics have been proposed [17]-[22]. However, only some have been developed for the solar PV powered water 
pumping system [23]-[25]. In this way, there is the need of new proposals, especially for systems with SRM and reduced number of power switches.

This paper proposes a new DC-DC converter based on merged Sepic-Ćuk topologies applied to a four-phases $8 / 6$ SRM drive. The proposed DC-DC converter topology is composed by a single power device with reduced blocking voltage, achieving a good efficiency and high-voltage gain. Since the proposed DC-DC converter is controlled in order to ensure the maximum power of the solar PV array, the proposed solution is ideal for water pumping systems with storage tanks, taking advantage of all the water flow available at the moment as result of the motor speed variation. The validation of the theoretical concepts will be supported by some simulation and experimental results.

\section{PROPOSED SOLUTION}

The proposed solution combines several systems, namely a solar PV array, a DC-DC converter with MPPT (maximum power point tracking) algorithm, an Asymmetrical Half-Bridge (AHB) converter and a centrifugal pump powered by a fourphase 8/6 SRM, as presented in Fig. 1. Due to the proposed DC-DC converter, the four-phases of the 8/6 SRM can have a common star winding connection and, consequently, the AHB converter is composed by four branches only. Additionally, the solar PV array is connected to the common star winding connection of the SRM, reducing the common-mode voltage generated by both DC-DC converter and AHB converter.

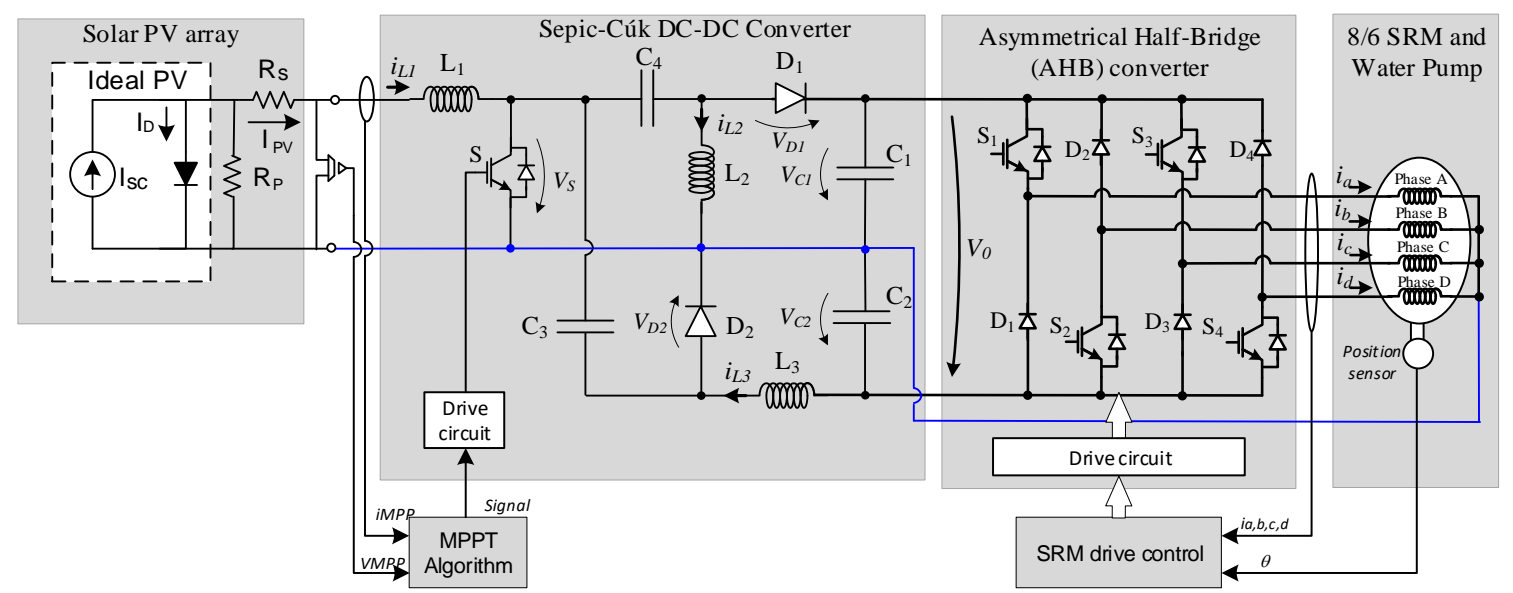

Fig. 1. Detail diagram of the proposed solution.

\section{A. PV Array}

A solar panel cell is basically a p-n semiconductor junction. When exposed to the light, a DC current is generated. The generated current varies linearly with the solar irradiance [26]. The equivalent electrical circuit of an ideal solar cell can be treated as a current source in parallel with a diode as shown in Fig. 2, where $I_{S C}$ denotes the current due to the solar irradiation $G$, and module cell temperature $T$. The series and parallel equivalent resistance are represented by $R_{S}$ and $R_{P}$ respectively.

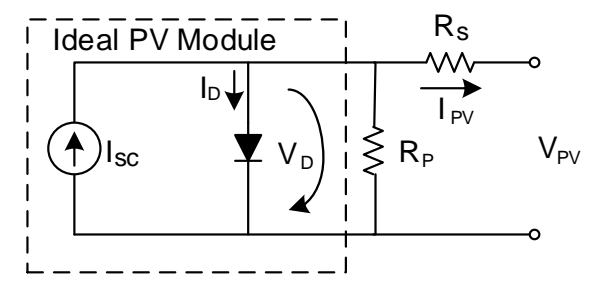

Fig. 2. Electric equivalent circuit of an ideal solar cell.

From the analysis of the circuit by the Kirchhoff laws, the following relationship between currents can be obtained for an ideal solar cell:

$$
I_{S C}=I_{D}+\frac{V_{D}}{R_{P}}+I_{P V}
$$

In this model, the diode represents the $\mathrm{p}$-n junction and its (dark) current $I_{D}(2)$ is dependent of the output voltage $V_{D}$, where $V_{T}$ (3) is the thermal voltage; $n$ is the ideality factor of the diode and $I_{O}$ the saturation current.

$$
I_{D}=I_{O}\left(\exp \left(\frac{V_{D}}{n V_{T}}\right)-1\right)
$$

The thermal voltage for a $P V$ with $N_{\text {cell }}$ is given by (3), where $k$ is the Boltzmann constant; $q$ is the elementary charge and $T$ the temperature. The output voltage of the solar $P V$ with $N_{\text {cell }}$ modules is expressed by (4).

$$
\begin{gathered}
V_{T}=\frac{k \cdot T N_{\text {cell }}}{q} ; \\
V_{P V}=V_{D}-\left(R_{S} I_{P V}\right)
\end{gathered}
$$

Neglecting the effect of the parallel resistance $R_{P}$, the following simplified $I-V$ characteristic can be obtained (5): 


$$
I_{P V}=I_{S C}-I_{O}\left(\exp \left(\frac{\left(V_{P V}+R_{S} I_{P V}\right) q}{n k T N_{\text {Cell }}}\right)-1\right)
$$

Because the DC voltage produced by a single solar panel cell is usually reduced it is normal to associate several cells to increase the voltage, creating a PV array.

\section{B. DC-DC Converter}

The proposed DC-DC converter is the combination of a "Sepic" and "Ćuk" converters $[27,28]$, in which both have the same voltage conversion ratio (Vo/Vi) and the same number of active and passive elements but with opposite polarity regarding the common connection point (see Fig. 3).

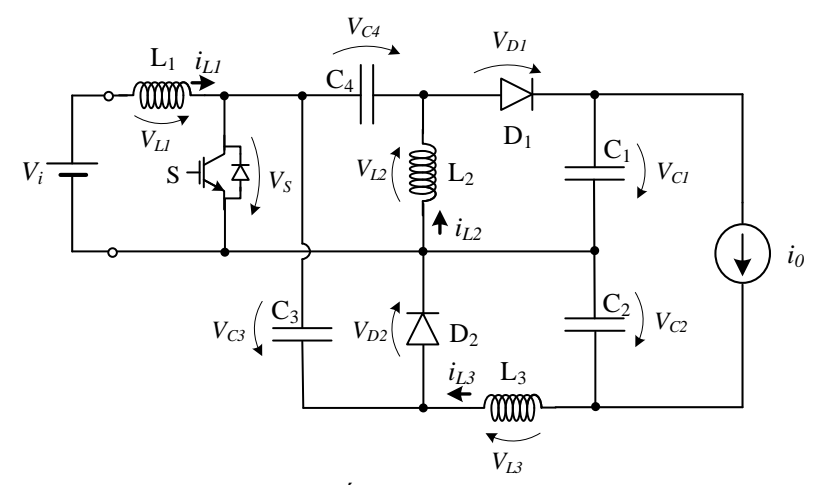

Fig. 3. Proposed merged Sepic-Ćuk DC-DC.

This converter is composed by a single power device in order to control both converters and, therefore, there is no need of synchronization with other switches. This converter can create a double output voltage with opposite polarity with a common connection point which can be used to connect to the middle point of the SRM with a star winding connection as described later. The proposed hybrid DC-DC topology is analyzed based on the assumption that the converter operates in continuous conduction mode and all components are ideal. According to this, the following three operating modes can be described:

- Operating mode I (Fig. 4(a)): This operating mode is effective when the power switch $\mathrm{S}$ is ON. The inductors L1, L2 and L3 are in charging mode while capacitor C3 and $\mathrm{C} 4$ are in discharging. Diode D1 is blocked due to negative voltage between $\mathrm{C} 1$ and $\mathrm{C} 4$. Diode D2 is blocked due to the negative voltage of $\mathrm{C} 3$ (VC3). In this mode $\mathrm{C} 1$ discharges faster than $\mathrm{C} 2$ producing a small voltage unbalance.

- Operating mode II (Fig. 4(b)): This mode starts when the power switch $\mathrm{S}$ turns off. The inductors L1 and L2 discharge the energy over the capacitors $\mathrm{C} 1$ and $\mathrm{C} 4$. During this mode, diode D2 is temporarily blocked due to the small unbalance between $\mathrm{C} 1$ and $\mathrm{C} 2$ as result of previous operating mode and consequently the inductor L3 imposes the discharge of $\mathrm{C} 3$. When the voltage of capacitor $\mathrm{C} 1$ approaches the voltage of $\mathrm{C} 2$, D2 turns on, starting the next operating mode. The duration of this mode depends on the load condition and consequently the discharge level of capacitor $\mathrm{C} 1$, but it is usually very small compared with $T s$. This can be considered as a transient mode.

- Operating mode III (Fig. 4(c)): In this operating mode the power switch S stays turned off and the diode D2 turns on as result of the voltage balance between $\mathrm{C} 1$ and $\mathrm{C} 2$. In this operating mode all the inductors discharge the energy over the capacitors and all the diodes (D1 and D2) are turned on.

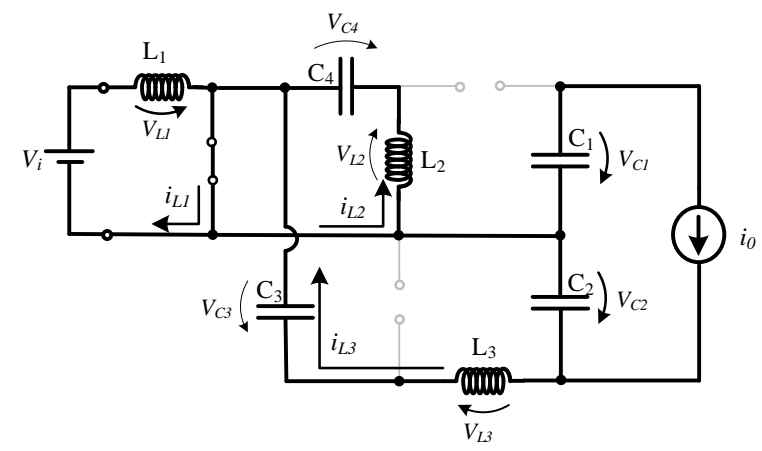

(a)

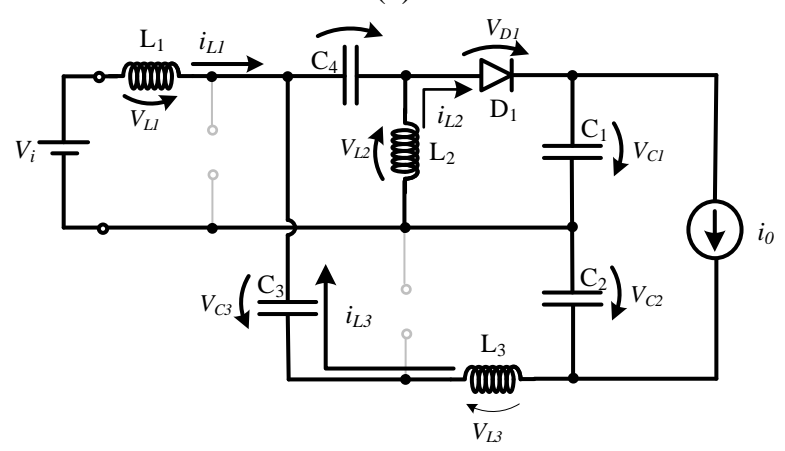

(b)

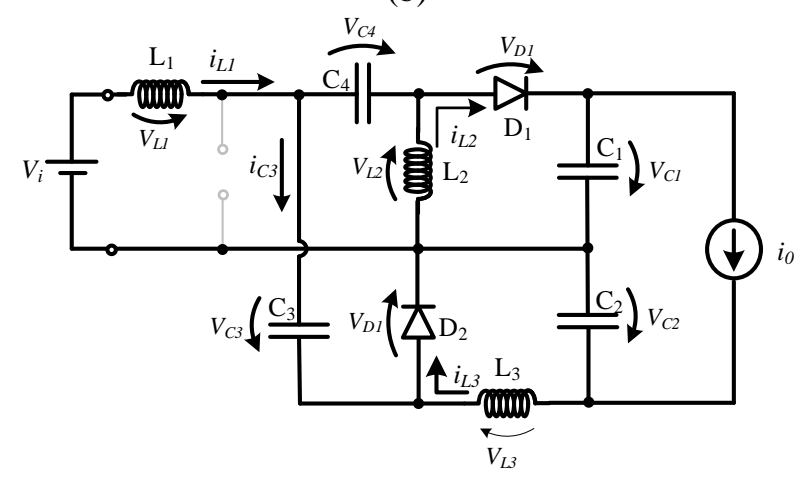

(c)

Fig. 4. Converter operating modes.

From the analysis of operating mode, I and III it's possible to obtain the voltage gain of this converter in continuous conduction mode $(C C M)$ operation. Thus, considering that the average voltages in the inductors L1, L2 and L3 in the operating modes I and III are equal, the following relationships are obtained:

$$
\delta V_{i}+(1-\delta)\left(V_{i}-V_{C 4}-V_{C 1}\right)=0
$$




$$
\begin{gathered}
\delta V_{C 4}+(1-\delta)\left(-V_{C 1}\right)=0 \\
\delta\left(V_{C 3}-V_{C 2}\right)+(1-\delta)\left(-V_{C 2}\right)=0
\end{gathered}
$$

Combining (6) and (7) it's possible to obtain the static voltage conversion ratio between $V_{C 1}$ and $V_{i}$ (9) which is the voltage ratio of a classic SEPIC converter.

$$
\frac{V_{C 1}}{V_{i}}=\frac{\delta}{(1-\delta)}
$$

Combining (6), (7) and (8) is possible to obtain (10). The result of (10) can be combined with (8) to obtain the static voltage conversion ratio between $V_{C 2}$ and $V_{i}(11)$ which is the voltage ratio of a classic Ćuk converter.

$$
\begin{gathered}
V_{i}=\left(V_{C 3}-V_{C 2}\right) \\
\frac{V_{C 2}}{V_{i}}=\frac{\delta}{(1-\delta)}
\end{gathered}
$$

The extended static voltage gain of the proposed hybrid DC-DC converter in CCM is the sum of the two voltage ratios (or gains) of the two classical converters, given in (12):

$$
\frac{V_{C 1}+V_{C 2}}{V_{i}}=\frac{V_{O}}{V_{i}}=\frac{2 \delta}{(1-\delta)}
$$

\section{MPPT Control Mode}

The problem considered by MPPT techniques is to automatically find the voltage VMPP or current IMPP at which a PV array should operate to obtain the maximum power output PMPP under a given temperature and irradiance. In this paper the MPPT algorithm adopted was the Perturb and Observe $(\mathrm{P} \& \mathrm{O})$ [27] and its flowchart is presented in Fig. 5.

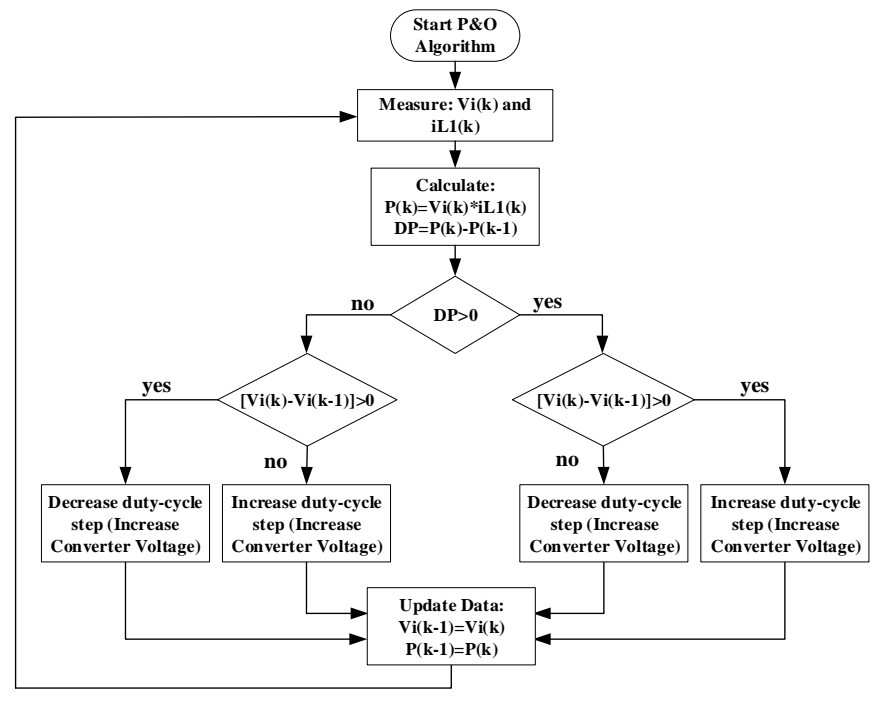

Fig. 5. Perturb and Observe MPPT algorithm [27].

This is one of the most used algorithms for peak power tracking due to its simplicity and reliability. It is based on the simple process of increment a little perturbation on the duty cycle and subsequent observation if the power is rising up or going down. If it is raising up the perturbation proceeds in the same direction, if the power is going down the perturbation inverts its direction.

\section{SRM drive}

To describe the SRM operation principle it is necessary to recall that the reluctance of the machine magnetic circuit and its variations are dependent on the rotor position. The variation of the magnetic reluctance in the SRM is essential to have torque (reluctance torque), and it can be properly controlled by accurately controlling the time of energizing and deenergizing the stator phases. In this machine the torque $\left(T_{j}\right)$ developed by each phase can be expressed by (13) as function of phase current, $i_{j}$, self-inductance coefficient $\left(L_{j}\right)$ which depends on the rotor position.

$$
T_{j}\left(\theta_{r}, i_{j}\right)=\frac{1}{2} \frac{d L_{j}\left(\theta_{r}\right)}{d \theta_{r}} i_{j}^{2}
$$

The methodology adopted to produce torque on this machine is based in a simple flat top PWM current controller as presented in the Fig. 6.

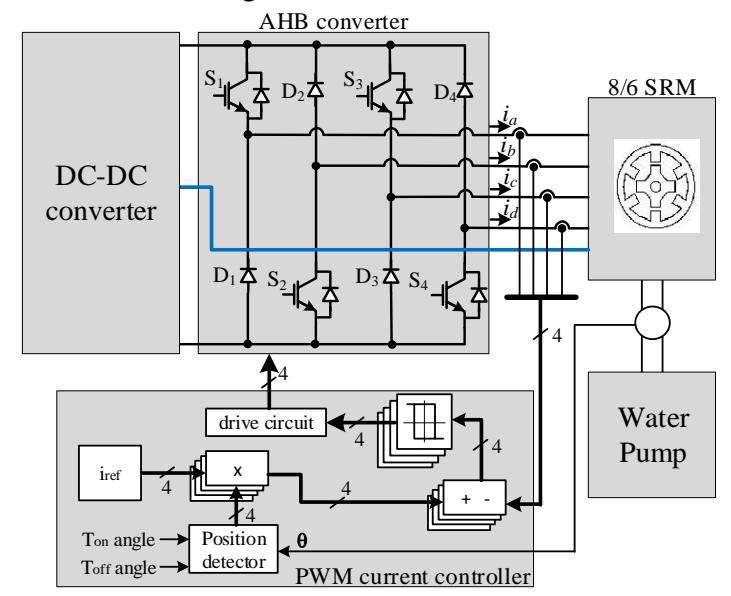

Fig. 6. PWM current control solution of SRM drive.

The current reference $\left(i_{r e f}\right)$ of the controller is the nominal value of the SRM machine nameplate. In this way all the energy produced by the solar PV array in each moment can be used to produce torque in the SRM machine up to the nominal value. Even when solar irradiation decreases, the MPPT is used to obtain the maximum power output in the specific moment. The available power output will be used to maintain the SRM machine running (and the water pump) even at reduced speeds. The operation limits of this solution for water pumping purposes should be determined by the minimum water flow rate required, necessary head (elevation) and Net Positive Suction Head (NPSH).

\section{SIMULATION AND EXPERIMENTAL RESULTS}

The proposed solution was simulated using the MATLAB/Simulink software. For the simulation of the solar PV array, it was chosen the ideal model described in section II. The data for this model was obtained from the commercial PV 
SGP-320W36V Poly Solar Panel and four PV panels were considered in the simulation. The proposed DC-DC converter was simulated in dynamic operation using the PV model as the power source and the SRM drive as load. A typical quadratic torque load was adopted in order to simulate the water pump. The MPPT algorithm was designed to continually control the duty-cycle of the DC-DC converter. The values selected for the passive components were $\mathrm{L} 1=\mathrm{L} 2=\mathrm{L} 3=1 \mathrm{mH}, \mathrm{C} 1=\mathrm{C} 2=$ $150 \mu \mathrm{F}$ and $\mathrm{C} 3=\mathrm{C} 4=20 \mu \mathrm{F}$. The experimental results were obtained from a developed prototype in order to confirm the characteristics of the proposed solution. As PV panels were not available a remotely controlled DC power source (EA-PS 8160-60) was used. This power supply was controlled by a dSPACE DS1104 considering the I-V curves of the PV panels. The passive components of the DC-DC prototype are similar to those selected in the simulation. The SRM drive is composed by an asymmetrical half-bridge converter and a four-phase 1.2 $\mathrm{kW}, 220 \mathrm{~V}, 1850 \mathrm{rpm}, 8 / 6 \mathrm{SRM}$. The PWM current controller of the SRM drive was also implemented in the dSPACE DS1104. A ventilator was used to simulate the mechanical load. Fig. 7 a) shows the simulation result of the DC-DC input voltage (Vi), capacitor voltages ( $\mathrm{Vc} 1$ and $\mathrm{Vc} 2$ ) and the DC-DC output voltage (Vo) when connected to the SRM drive. This figure shows that the relationship between the input and output voltage is approximately $3(\mathrm{Vo} / \mathrm{Vi})$. In this simulation result is possible to confirm that the voltages of the output capacitors are almost equal and half of the total output voltage $(\mathrm{Vc} 1=$ $\mathrm{Vc} 2=\mathrm{Vo} / 2)$. Note that the AHB converter uses the $\mathrm{Vc} 1$ and $\mathrm{Vc} 2$ voltages (around $220 \mathrm{~V}$ in this case) for each motor winding. Fig. 7 b) shows an experimental result in similar conditions and according to what was expected.

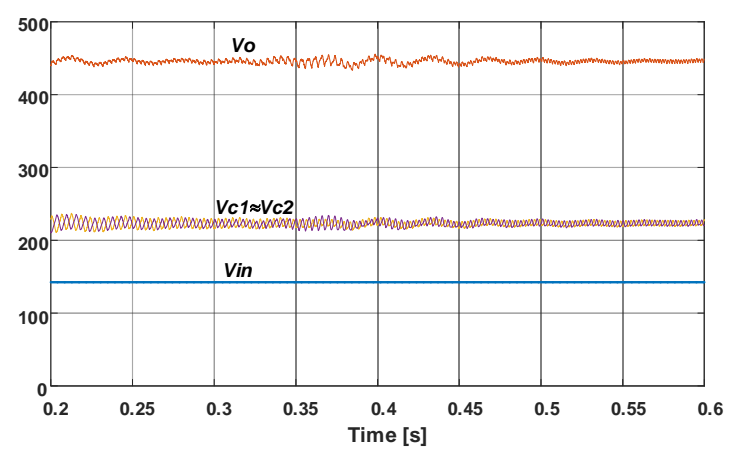

(a)

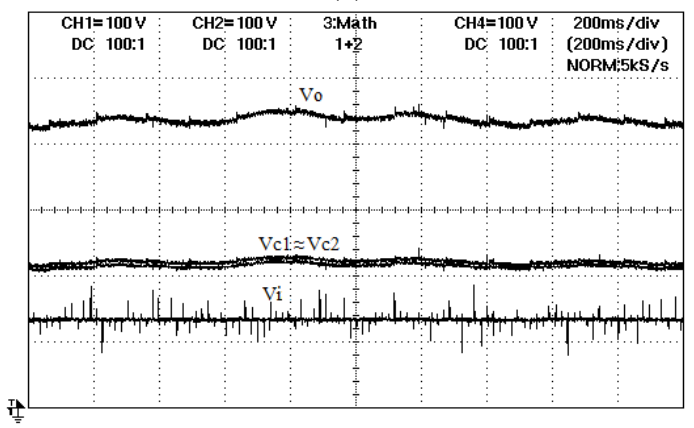

(b)

Fig. 7. Simulation results of the DC-DC converter: (a) input voltage, capacitors and output voltage $\mathrm{Vi}, \mathrm{V}_{\mathrm{c} 1}, \mathrm{~V}_{\mathrm{c} 1}$ and $\mathrm{V}_{\mathrm{o}}$; (b) Experimental result in similar conditions.
Fig. 8 shows the simulation and experimental result of the current in all the inductors of the DC-DC converter considering that the converter is connected to the SRM drive and water pump. In this figure is possible to see the current dynamics in the DC-DC converter due to the PWM current control in the drive.

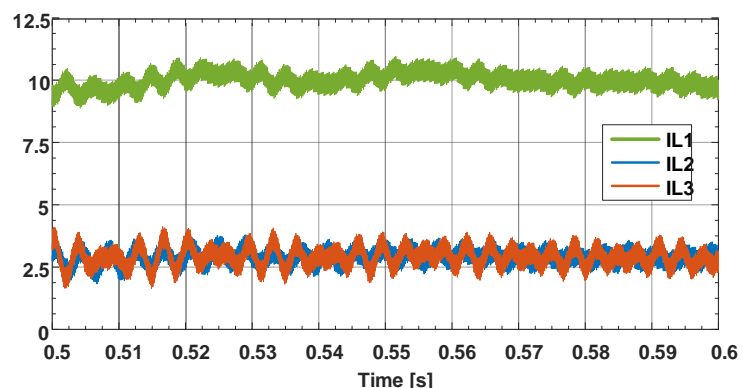

(a)

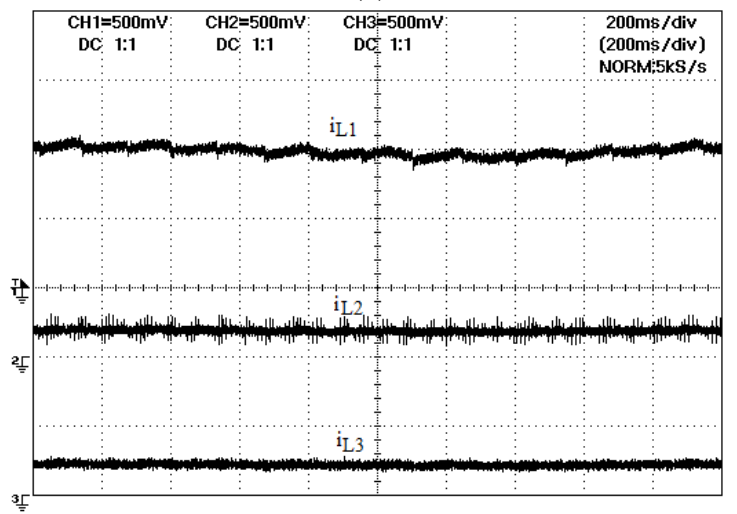

(b)

Fig. 8. DC-DC converter inductor currents $\mathrm{i}_{\mathrm{L} 1}$, $\mathrm{i}_{\mathrm{L} 2}$ and $\mathrm{i}_{\mathrm{L} 3}$ : (a) Simulation result; (b) Experimental results with 5A/div.

The simulation and experimental result of the 8/6 SRM drive is presented in fig. 9. In this figure it's possible to see the current waveforms ( $i a, i b$, ic and id) of the 4-phases, the electromagnetic torque $(T e)$ and the speed motor $(\omega \mathrm{m})$ when coupled to a water pump during the motor acceleration. The water pump was simulated using a quadratic torque load. The experimental results show that the behavior of the $8 / 6$ SRM drive is similar to those presented in the simulation results and according to what was expected in this situation.

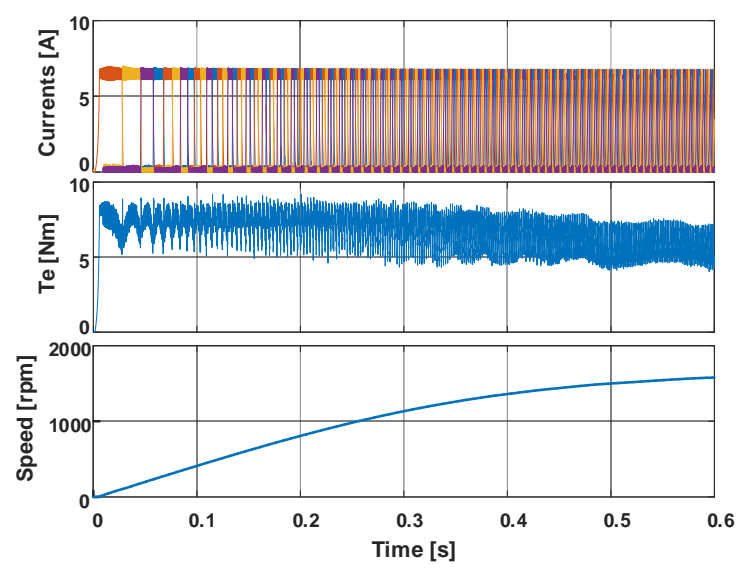

(a) 


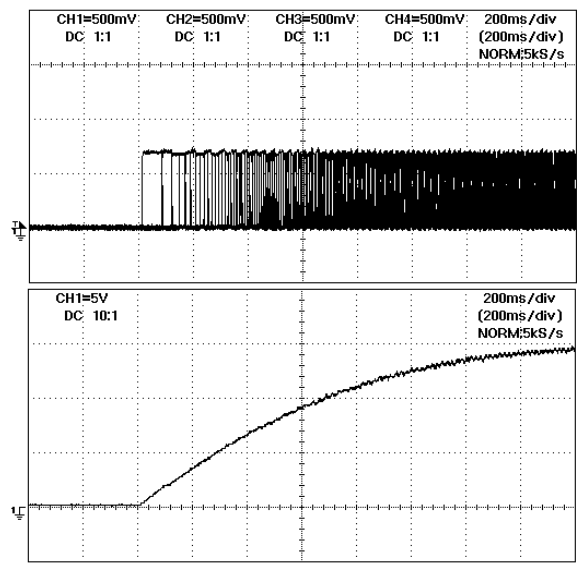

(b)

Fig. 9. Current waveforms, electromagnetic torque and speed of the 8/6 SRM during acceleration: (a) - Simulation results; (b) Experimental results.

\section{CONCLUSIONS}

A solar photovoltaic (SPV) powered water pumping system employing a switched reluctance motor (SRM) and a merged Sepic-Cúk DC-DC converter was presented in this paper. The proposed DC-DC converter has a single active power switch, presents high-voltage gain and dual output voltage. The use of this DC-DC converter allows to use an AHB converter with reduced number of active power switches. The performance of the proposed solution was tested and verified through several computer simulations and some experimental results using a laboratorial prototype developed for this purpose. The obtained results allowed to confirm the expected theoretical considerations.

\section{REFERENCES}

[1] F. Blaabjerg, K. Ma, "Wind Energy Systems," Proceedings of the IEEE, Vol. 105, no. 11, pp. 2116-2131, Nov. 2017.

[2] S. A. Sherif, F. Barbir, T. N. Veziroglu, "Wind energy and the hydrogen economy - review of the technology," Elsevier, Solar Energy, Vol. 78, no. 5, pp. 647-660, May 2005.

[3] J. Antonanzas, N. Osorio, R. Escobar, R. Urraca, F. J. Martinez-dePisona, T. F. Antonanzas "Review of photovoltaic power forecasting," Elsevier, Solar Energy, vol. 136 (15), pp. 78-111, Oct. 2016.

[4] G. K. Singh, "Solar power generation by PV (Photovoltaic) technology: A review," Energy, vol. 53, no. 1, pp. 1-13, May 2013.

[5] Renewables 2017, IEA, Market Report Series, 2017. www.iea.org/Textbase/npsum/renew2017MRSsum.pdf.

[6] M. Chergui, M Benaissa, "Strategy photovoltaic pumping system in scattered area", Proc. $4^{\text {th }}$ Int. Conf. on Renew. Ener. Research and Appl. (ICRERA), pp. 283-286, Palermo, Italy, 22-25 Nov. 2015.

[7] O. Cisse, M. F. Ndiaye, W. M. Nkounga, P. A. Ndiaye, A. Sioutas, "Water and Energy Management based on Fuzzy Logic and Linear Programming for a Photovoltaic/ Wind/Battery Pumping System in Rural Environment," Proc. 7th Int. Conf. on Renew. Ener. Research and Appl. (ICRERA), pp. 1115-1120, Paris, France, 14-17 Oct. 2018

[8] V. F. Pires, D. Foito, A. Cordeiro, J. F. Silva, "A Single-Switch DC/DC Buck-Boost Converter with Extended Output Voltage," Proc. 7th International Conference on Renewable Energy Research and Applications (ICRERA), pp. 791-796, Paris, France, 14-17 Oct. 2018.

[9] V. K. Koreboina, B. L. Narasimharaju, D. M. Kumar, "Performance investigation of simplified PWM MPPT approach for direct PV-fed switched reluctance motor in water pumping system," IET Electric Power Applications, vol. 11, no. 9, pp. 1645 - 1655, Nov. 2017.
[10] Mishra, A. K., Bhim Singh, B., "A single stage solar PV array-based water pumping system using SRM drive," IEEE Industry Applications Society Annual Meeting, pp. 1-8, Nov. 2016.

[11] Gonzalez-Llorente, J., Ortiz-Rivera, E. I., Salazar-Llinas, A., JimenezBrea, E., "Analyzing the optimal matching of dc motors to photovoltaic modules via dc-dc converters," 25th Annu. IEEE Appl. Power Electron. Conf. Expo., pp. 1062-1068, 21-25 Feb. 2010.

[12] S. Ebrahim, M. Badr, A. Elgendy, P- Jain, "ANN-Based optimal energy control of induction motor drive in pumping applications," IEEE Trans. Energy Convers., vol. 25, no. 3, pp. 652-660, Sept. 2010.

[13] Abdelrahman, A., Hamouda, M. and Youssef, M., "A cost-effective BLDC drive for the water pump application: Analysis, design, and experimentation,” Proc. IEEE Transp. Electrif. Conf. Expo, Asia-Pacific, Busan, South Korea, pp. 240-245, June 2016.

[14] Chandrasekaran, N. and Thyagarajah, K., "Modeling and performance study of single-phase induction motor in PV fed pumping system using MATLAB,” Int. Journal Elect. Engin., vol. 5, no. 3, pp. 305-316, 2012.

[15] Sashidhar, S. and Fernandes, B. G., "Comparison of a ferrite based single, three-phase spoke and surface permanent magnet BLDC motor for a PV submersible water pump," Proc. IEEE International Conference on Industrial Technology (IClT), Seville, Spain, pp. 671-676, 2015.

[16] Hu, Y., Gan, C., Cao, W., Fang, Y., Stephen, F. and Wu, J., "Solar PV Powered SRM Drive for EVs with Flexible Energy Control Functions," IEEE Trans. Ind. Appl., vol. 52, no. 4, pp. 3357-3366, Jan. 2016.

[17] S. Ikeda, F. Kurokawa, "Isolated and wide imput ranged boost full bridge DC-DC converter for improved resilience of renewable energy systems," Proc. 6th Int.1 Conf. Ren. Energy Research and Applications (ICRERA), pp. 290 - 295, San Diego, CA, USA, 5-8 Nov. 2017.

[18] V. F. Pires, A. Cordeiro, D. Foito, J. F. Silva, "High Step-Up DC-DC Converter for Fuel Cell Vehicles Based on Merged Quadratic BoostĆuk", IEEE Transactions on Vehicular Technology, vol. 68, Issue 8, pp. 7521-7530, August 2019.

[19] S. R. Addula, P. Mahalingam, "Coupled Inductor Based Soft Switched Interleaved DC-DC Converter for PV Applications", International Journal of Renewable Energy Research (IJRER), Vol 6 (2), June 2016.

[20] V. F. Pires, D. Foito, A. Cordeiro, "A DC-DC Converter With Quadratic Gain and Bidirectional Capability for Batteries/Supercapacitors", IEEE Transactions on Industry Applications, vol. 54, Issue: 1, pp. 274-285, January/February 2018.

[21] C. Rani, C. Hussain Basha, S. Odofin, "A Review on Non-isolated Inductor Coupled DC-DC Converter for Photovoltaic Grid-Connected Applications", IJRER 2017, Vol 7 (4) December 2017.

[22] V. F. Pires, D. Foito, F. R. B. Batista, J. F. Silva, "A photovoltaic generator system with a DC/DC converter based on an integrated BoostĆuk topology", Solar Energy, vol. 136, pp. 1-9, October 2016

[23] A. K. Mishra, B. Singh, "Solar PV Powered SRM Driven Water Pumping System using Landsman Converter," IEEE International Conference on Power Electronics, Drives and Energy Systems (PEDES), pp. 1-6, Trivandrum, India, 14-17 Dec. 2016.

[24] V. Gali, P. Amrutha, "Fast dynamic response of SEPIC converter based photovoltaic DC motor drive for water pumping system," Int. Conf. on Circuit, Power and Comp. Techn., pp. 1-5, March 2016.

[25] E. Lorenzo, Solar Electricity: Engineering of Photovoltaic Systems, Progensa, 1994.

[26] P. V. Devika, R. Parackal, "SEPIC-CUK Converter For PV Application Using Maximum Power Point Tracking Method", International Conference on Control, Power, Communication and Computing Technologies ICCPCCT'2018, pp. 266-272, March 2018.

[27] E. Jimenez-Toribio,A. A. Labour-Castro, F. Muniz-Rodriguez, H. R. Perez-Hernandez, E. I. Ortiz-Rivera, "Sensorless Control of SEPIC and Ćuk Converters for DC Motors using Solar Panels", IEEE International Electric Machines and Drives Conference, pp. 1503-1510, 2009.

[28] K. H. Hussein, I. Muta, T. Hshino, M. Osakada, "Maximum photovoltaic power tracking: an algorithm for rapidly changing atmospheric conditions," Generation, Transmission and Distribution, IEEE Proceedings., Vol. 142 (1) Jan. 1995. pp. 59-64. 